\title{
Environmental Politics and Economic Development
}

\author{
Roger D. Congleton \\ Center for Study of Public Choice \\ George Mason University
}

$7-1-02$

\section{Introduction:}

\section{A. Environmental Problems Are Political Rather than Economic}

In most economic textbooks, environmental problems are considered to be economic in origin. Industrial producers of product $\mathrm{X}$ use the air or water system to dispose of noxious waste $Z$, which imposes costs on individuals who live downstream or downwind from the site at which $\mathrm{X}$ is produced. The lower cost of this method of disposal implies that consumers benefit from lower prices of $\mathrm{X}$, while firm owners may benefit from higher profits according to market structure. In either case, neither suppliers nor consumers of $\mathrm{X}$ have an incentive to account for the spillover costs that the production of $\mathrm{X}$ imposes on persons living downstream or downwind from the site of production. Consequently, from the perspective of welfare economics, product $\mathrm{X}$ is overproduced and the air and water systems are overutilized as methods of waste disposal.

Of course, as Coase (1960) points out, externality problems can be solved by marketlike transactions. Those individuals affected by the spillovers could band together and pay the firm owners to use different methods of waste disposal. However, what Coase neglects is that such coordinated activities require solutions to a host of organizational problems: a method of collective decision making would have to be chosen, a method of collecting contributions would be required, and so forth. Forming such organizations are problematic, because, as Olson (1965) pointed out, such collective activities have associated public goods and political problems that few persons will have incentives to solve. Perhaps more important, the rewards of public service entrepreneurship tend to be smaller than those generated by entrepreneurship in markets, thus, fewer public goods problems tend to be solved than private goods problems. 
Alternatively, rather than organizing to negotiate with producers and consumers of product $\mathrm{X}$, those living downstream or downwind could lobby government to regulate or tax the production of $\mathrm{X}$. That is to say, rather than form a regional organization with complete negotiation powers for the interests represented, those living downwind or downstream can form a less complex organization that attempts to persuade government to solve the problem for them. Not only does lobbying reduce the affected group's organization costs, it tends to require smaller ongoing sacrifices by individual members of the downwind group, because producers and consumers of $\mathrm{X}$ no longer need be fully compensated by those demanding smaller emissions. These cost advantages provide a rational choice explanation for the fact that domestic environmental policies tend to be matters decided by governments, rather than negotiated between large environmental clubs and polluters. ${ }^{1}$

It bears noting that once an externality problem is brought to the attention of government, its continuation or amelioration is a result of government policy. That is to say, if no new specific or general policy is put in place, the resulting pollution level reflects incentives already present in civil and environmental law. If regulations are put in place, the resulting pollution level is substantially determined by the regulatory targets and the enforcement of environmental regulations. In this sense, it is "politics" rather than "economics" that is ultimately responsible for ongoing pollution, because it is government policies that frame the decisions of firms and consumers that generate the pollution.

1 It bears noting that prospects for Coasian solutions are also affected by a variety of government policies and may require changing those policies. First, the initial assignment of rights determine what course of action is necessary. Within governments characterized by an aggressive tort law, those living downstream or downwind could launch a class action suit against the producers for damages imposed by the use of the air or water systems to dispose of waste products. In the absence of such legal remedies, a new organization would have to be created to collect money in order to compensate producers and consumers of X. Such organizations would require some process of collective choice to determine negotiation strategies, assign cost shares to members, and design methods for punishing those who fail to contribute. Government policies may affect such internal arrangements of such groups or special service districts insofar as its policies discourages interest group formation (as within dictatorships), is neutral toward them, or actively encourages them.

In the end, the Coasian result reflects a variety of government policies that affect organizational costs, contract enforcement, and liability under tort law. 
This conclusion also applies to other more fundamental areas of environmental law. Resources can be privately held and managed, collectively held and managed, or private and collective management can be intermingled in a variety of ways (Ostrom, 1990). Producers are either free to use the air and water systems for waste disposal or pay an implicit or explicit regulatory price to use these systems. In all these cases, the final use of natural resources reflects incentives latent in government policies. That is to say, all ongoing environmental problems are consequences of economic equilibria generated by ongoing political equilibria. In this sense, environmental problems are fundamentally political--outcomes of collective choice--rather than market failures.

\section{B. Environmental Problems Are Ancient and Fundamental}

There is an unfortunate modern tendency to define "environmental policy" as that which is addressed by modern environmental agencies. This method of defining environmental policy is misleading for several reasons. The most important of these is that it focuses our attention on the subset of environmental problems that have been addressed only fairly recently, and thereby greatly understates the true dimension of environmental law and its long history. Environmental problems have long been addressed by societies, because long-term settlements or towns are only possible if a variety of water supply and waste disposal problems are solved. Either the trash has to be moved periodically out of town, or the town itself has to be moved periodically--as with nomadic villages.

Evidence of externality and environmental concerns can be found in a variety of ancient sources. For example: the Code of Hammurabi (1700 BCE) discusses the rights of property owners and among many other rules, specifies that:

(53) If any one be too lazy to keep his dam in proper condition, and does not so keep it; if then the dam break and all the fields be flooded, then shall he in whose dam the break occurred be sold for money, and the money shall replace the corn which he has caused to be ruined.

or

(55) If any one open his ditches to water his crop, but is careless, and the water flood the field of his neighbor, then he shall pay his neighbor corn for his loss. 
A good deal later, Aristotle (330 BCE) explicitly notes that an ideal community should take account of environmental quality:

"I mention situation and water supply in particular because air and water, being just those things that we make most frequent and constant use of, have the greatest effect on our bodily condition. Hence, in a state which has [the] welfare [of its citizens] at heart, water for human consumption should be separated from water for all other purposes." (The Politics, 1969 p. 278)

Environmental prerequisites for a comfortable and healthy life have long been recognized as practical political matters essential to economic prosperity. ${ }^{2}$ What has varied through time are the methods by which policies are chosen and the assessments of environmental amenities and risks, which are affected by constitutional and legal traditions, aesthetic assessments, and the technological feasibility of alternative uses of natural and human resources. Both property law and tort law are important methods for addressing externality and commons problems.

\section{Contemporary Environmental Politics and Policies}

\section{A. The Median Voter and Environmental Policy}

Within democracies, a useful first approximation of public policy is that the median voter gets what he or she wants. In most cases, voters will have a broad range of views on the ideal environmental policies. Each voter will favor the policies that maximize his or her utility given his or her understanding of the benefits and costs of environmental problems and amenities. When voters have a direct interest in environmental amenities, such as public green spaces, each voter's preferred policy will reflect both his or her marginal subjective benefit from the service and the marginal tax cost of that service. That is to say, a voter's demand for such environmental services is much the same as that for roads, schools, or fire protection. Electoral

$2 \quad$ Natural phenomena play such an important role in both hunting and agriculture based societies that very often "nature" has been the basis of metaphysical and religious beliefs. Even today, various forms of nature worship or pantheism are among the most common religions worldwide. In what is clearly a fortuitous consequence of environmental regulations adopted by the civilizations of antiquity, community waste disposal sites and burial grounds have greatly added to our knowledge of these ancient societies by providing a material basis for the research of archeologists. 
demand rises as tax prices fall, median income rises, or median tastes become "greener" through time.

In other cases, the demand for environmental quality is indirect. For example, environmental regulations are often demanded as a method of reducing health risks. Here the service demanded is health or wealth rather than environmental quality, per se. In such cases, the median voter's demand for environmental quality is also affected by his or her assessment of the causal connection between particular aspects of environmental quality and health. Health is, or may be, affected by such environmental factors as household exposure to radon, lead, and arsenic; ongoing exposure to effluents transported by air and water; and indirect consequences of large- scale environmental changes as may be associated with density changes of ozone in the stratosphere or climate change. In such cases, it is clear that environmental and medical theories play an important role in determining the median voter's preferred environmental policy. As the median voter's perceived health risks of a given effluent increase, the median demand for environmental regulation tends to increase.

Unfortunately, the median voter cannot perfectly assess the costs or benefits of alterna-

tive environmental policies, because he or she is neither a tax expert, an environmental scientist, nor a health expert. Indeed, even experts disagree about both environmental theories and health risks. Consequently, a good deal of the median voter's demand for environmental regulation is based on secondhand knowledge of the opposing views of experts, rather than on direct personal experience--in contrast to the median demand for mass transit or public education. This is another sense in which the median voter's demand for environmental quality can be said to be indirect.

\section{B. Interest Groups}

A wide variety of electoral competition models yields median voter or near median voter outcomes in settings where competition is intense, voters are very well informed and vote independently, and candidates choose policy positions to maximize chances of electoral success. However, in other settings, the median voter model has to be modified in a variety of ways. In settings where voters are imperfectly informed, organized groups may be able to 
persuade voters to change their minds about the relative merits of policies or be able to persuade candidates to take positions on issues that voters largely remain unaware of. For example, relatively few voters in the United States will know the details of the Clean Air Act, the Endangered Species Act, or of the Kyoto Protocol. In such cases, even if the general sweep of policy is determined by electoral considerations (median voter interests), the details will not, insofar as they remain largely unknown to voters because they are costly to monitor and assess. In such policy areas, elected officials may safely trade policy positions for campaign resources or adopt policies to advance their nonelectoral interests.

There is clear anecdotal and statistical evidence that interest groups affect environmental policies, at least at the margin. For example, Coates (1996) demonstrates that campaign contributions affect the voting patterns of elected legislators on environmental issues. Cropper et. al. (1992) demonstrate that EPA policies appear to be influenced by interest group testimony and law suits. Buchanan and Tullock (1976) argue that economic rather than environmental considerations often determine the choice of policy instruments.

The effects of interest groups is greatest in areas where the demand for environmental policies is indirect, because interest groups have wider latitude to persuade voters on matters they have little or no direct experience with. In such cases, interest groups attempt to influence the theories used by the median voter to assess policies in addition to their normal efforts to influence a voter's assessment of the tax costs and direct benefits associated with particular policies. Overall, the policies that are chosen in democracies reflect the effects of electoral competition, which causes policies to gravitate toward median voter preferences, and the influence of politically active interest groups inside and outside government.

\section{The Normative Valuation Problem}

In some cases, the information problems confronting voters (and legislatures) can be reduced by delegating decision making to an expert bureaucracy and charging it with maximizing social net benefits. This institutional solution maximizes average benefits rather than median benefits, but may yield policies that advance median voter interests most of the time if costbenefit analysis is "honestly" applied. The resulting policies will be approximately those that a 
median voter would have chosen if he or she had the time and energy to be well informed on the issues being decided.

Unfortunately, in the case of environmental policy, it is difficult to estimate the benefits and costs of alternative policies. This is not because benefits and costs are subjective, inasmuch as this is always the case, but rather because few market proxies for benefits typically exist, and, moreover, there is often significant disagreement over the effects of policy alternatives. For example, the marginal benefit of a large nature preserve in Alaska for tourists can be approximated from travel cost data, but not for nontourists who nonetheless favor such preserves. Moreover, even for tourists it is difficult to estimate the marginal effects of small changes in the size of a nature preserve. How many fewer tourists would come if the preserve were a bit smaller? A majority of voters may favor a large preserve, but what are they willing to pay for one that is 100 square miles larger or smaller? Unfortunately, even voters rarely know this themselves. In the end, even with completely neutral agencies interested in advancing the interests of the median voter, delegation is very difficult.

The problem of delegation becomes even more complicated when agency personnel have goals that differ significantly from those of the electoral mainstream. Evidence of such agency problems is developed by Van Houtven (1996), who demonstrates that the EPA has more than occasionally overstepped its legislative mandates. For example, the EPA has failed to use cost-benefit analysis when required to do so by law. It also used cost-benefit analysis elsewhere where it was not part of the policy mandate and occasionally where cost-benefit analysis was explicitly prohibited by statute.

\section{International Environmental Problems and Politics}

\section{A. Regulatory Externalities}

One of the more interesting contemporary areas of environmental politics concerns environmental problems that span national borders. International problems are of special interest for political analyses because international policies address regulatory failures rather than conventional economic externality problems. Regulatory failures arise because individual governments 
have only very weak incentives to take account of the effects that their environmental regulations have on neighboring countries.

The existence of regulatory externalities often implies that unrealized gains to trade in environmental regulations exist. Consider the case of two neighboring democracies separated by a river into which effluents may be discharged. Each government has an incentive to regulate discharges into the boundary water insofar as its citizens (median voter) demand improved water quality--whether for recreation or health reasons. However, neither government has an electoral reason for taking account of the benefits that its policies confer upon the other country's citizens. Under the usual public choice assumptions, self-interested voters behave in the same manner as ordinary consumers and neglect the effects of their electoral demands on other citizens, both within their own countries and in neighboring countries. The citizens of other countries do not vote in the relevant elections. The two countries' environmental regulations jointly determine the water quality of the boundary river by jointly determining the effluents discharged into it. Insofar as each country's electorate (median voter) values the water quality of the boundary river, each benefits from the other country's environmental regulations. In such cases, there are mutual gains that can be realized if both countries increase the stringency of their water quality regulations somewhat, and, moreover there are electoral reasons for attempting to do so (Hoyle, 1991, Congleton, 1992, Fredricksson, 2000b). Unless the two countries' environmental regulations are coordinated in some way, each tends to underregulate its discharges into the boundary waters.

\section{B. Only Coasian Solutions}

A second feature of international environmental problems of particular interest is that national sovereignty implies that regulatory externality problems can only be addressed via voluntary agreements, that is to say, via Coasian contract. A government will only sign an international agreement if the treaty advances its own interests and will only implement policies that do so. Such treaties will necessarily have to address a variety of institutional problems that can be neglected in domestic environmental policy (Congleton, 1995). For example, an environmental agreement cannot implement itself, because implementation by sovereign nations 
requires domestic legislation. The lack of international enforcement agencies implies that any Coasian contracts consummated must be self-enforcing (Barett, 1994, Schmidt, 1999). Overall, addressing international environmental problems are clearly more problematic than domestic ones because political considerations in several nations have to be accounted for.

The voluntary nature of international environmental agreements together with the wide range of government types and social settings implies that incentives to sign and implement international agreements vary widely (Congleton, 2001). For example, both the domestic environmental setting and type of government affect the ratification of environmental treaties. Murdock and Sandler (1997b) find that countries affected by upstream emissions are more likely to sign international treaties than those that are less affected by transboundary emissions. Congleton (1992) and Fredriksson (2000b) demonstrate, for example, that democracies are more inclined to sign and ratify treaties than nondemocracies. Even after a treaty is signed and ratified the overall impact of environmental treaties on domestic policies is uncertain, because, in practice, environmental treaties lack explicit enforcement provisions. Murdock and Sandler (1997a, 1997b) find that environmental treaties have little, if any, effect on a nation's environmental policies.

\section{Conclusion}

\section{A. Long-Run Environmental Political Economy}

Environmental policies, broadly interpreted, define man's relationship with the environment. They include all the rules that affect the use of natural resources, for any and all purposes. Insofar as politics has always played a role in determining those rules, it is clear that environmental and political considerations have long affected human law, and thereby economic development. Many of our fundamental property rights have evolved through time to address environmental problems associated with a variety of "tragedies of the commons" (Demsetz, 1967).

Polities that properly address environmental problems will look much different than ones that do not. Polities that fail to solve commons problems will find some resources overused 
and others underused, and have a citizenry that lives less comfortable and secure lives. Polities that neglect land management or fail to develop institutions that address such problems may find formerly fertile farm fields reduced to wastelands. Polities that fail to secure and protect potable water supplies will have a citizenry whose productivity is reduced by poor health and short lives. Polities that "overly protect" nature from economic uses will be less complex, less sophisticated, and poorer societies, although their natural surroundings may well be more varied and verdant.

Although the processes of economic development are complex, it is clear that the political considerations that constrain man's relationship with nature--the pattern of use rights, ownership, and restrictions--has played an important role in the course of economic development. In this respect, environmental politics is not simply a minor subarea of the economic theory of regulation, but a major area of long- and short-term policy development with profound consequences for economic and human development. Future policies are also likely to have such effects whether new methods for addressing global environmental problems are im-

plemented or not. Within environmental political economy, even the air that one breathes is endogenously determined!

\section{B. Politics as Usual?}

Nonetheless, environmental political economy is largely politics as usual. Environmental policies are, thus, examples of the wide range of political equilibria explored in the public choice literature.

The domain of environmental policy is unusually broad, which makes the politics of environmental policies especially interesting and controversial. Modern international environmental policy controversies address global phenomena beyond the reach of domestic governments, while raising profound normative questions about the proper response to uncertain, but possibly grave long-term risks. Even domestic environmental policy choices are highly contentious. Environmental regulations affect terms of trade within and between nations, and, therefore, attract significant attention from powerful economic interest groups such as the oil, chemical, and labor lobbies. The broad implications of environmental regulations and services and policies 
also attract significant interest from noneconomic interest groups whose members aim for conflicting visions of the good society. Moreover, environmental science is a relatively new field addressing issues that cut across many fields of science, and whose theories are continuously being updated. Environmental politics may be ordinary, but they are "ordinary" on a grand scale.

\section{REFERENCES}

Barett, S. (1994) "Self-Enforcing International Environmental Agreements," Oxford Economic Papers 46: 878-894.

Bevans, C. I. (1974) Treaties and Other International Agreements of the United States of America, Department of State Publication 8761.

Boadway, R. and Hayashi, M. (1999) "Country Size and the Voluntary Provision of International Public Goods," European Journal of Political Economy 15.

Buchanan, J. M. and Tullock, G. (1975) "Polluters' Profits and Political Response, Direct Control Versus Taxes," American Economic Review 65: 139-147.

Coase, R. H. (1960) "The Problem of Social Cost," Journal of Law and Economics 3: 1-44.

Coates, D. (1996) "Jobs versu Wilderness Areas: The Role of Campaign Contributions," Chapter 4 of Congleton, R. D. Ed. The Political Economy of Environmental Policy. Ann Arbor: University of Michigan Press.

Congleton, R. D. (1992) "Political Regimes and Pollution Control," Review of Economics and Statistics 74: 412-421.

Congleton, R. D. (1995) "Toward a Transactions Cost Theory of Environmental Treaties," Economia della Scelte Pubbliche, 119-139.

Congleton, R. D. Ed. (1996) The Political Economy of Environmental Policy. Ann Arbor: University of Michigan Press.

Congleton, R. D. (2001) "Governing the Global Environmental Commons: The Political Economy of International Environmental Treaties and Institutions," chapter 11 of Schulze, G. G. and Ursprung, H. W. Eds. Globalization and the Environment. New York: Oxford University Press.

Cropper, M., Evans, W. N., Berardi, S. J., Duela-Soares, M. M., and Portney, P. (1992) Journal of Political Economy 100: 175-197. 
Demsetz, H. (1967) "Towards a Theory of Property Rights," American Economic Review 57: 347-360.

Feld, L. P., Pommerehne, W. W., and Hart, A. (1996) "Private Provision of a Public Good," in R. D. Congleton, Ed., The Political Economy of Environmental Protection.

Fredriksson, P. G. and Gaston, N. (2000a) "Ratification of the 1992 Climate Change Convention: What Determines Legislative Delay?" Public Choice 104: 345-68

Fredriksson, P. G. and Noel, G. (2000b) "Environmental Governance in Federal Systems: The Effects of Capital Competition and Lobby Groups," Economic Inquiry 38: 501-14.

Fredriksson, P. G. (2001) "How Pollution Taxes may Increase Pollution and Reduce Net Revenues," Public Choice 107: 65-85.

Hoel, M. (1991) "Global Environmental Problems: The Effects of Unilateral Actions Taken by One Country," Journal of Environmental Economics and Management 21: 55-70.

Leidy, M. P. and Hoekman, B. M. (1996) "Pollution Abatement, Interest Groups, and Contingent Trade Policies," in R. D. Congleton, Ed. The Political Economy of Environmental Protection.

Maloney, M. T. and McCormick, R. E. (1982) "A Positive Theory of Environmental Quality Regulation," Journal of Law and Economics 25: 99-123.

Mueller, D. C. (1989) Public Choice II, Cambridge: Cambridge University Press.

Murdoch, J. C. and Sandler, T. (1997a) "The Voluntary Provision of a Pure Public Good: The Case of Reduced CFCs Emissions and the Montreal Protocol," Journal of Public Economics 63: 331-349.

Murdoch, J. C., Sandler, T., and Sargent, K. (1997b) "A Tale of Two Collectives: Sulfur versus Nitrogen Oxides Emission Reduction in Europe," Economica 64: 281-301.

Olson, M. (1965) The Logic of Collective Action. Cambridge, Mass: Harvard University Press, 1965.

Ostrom, E. (1990) Governing the Commons: the Evolution of Institutions for Collective Action. New York: Cambridge University Press.

Peltzman, S. (1976) "Toward a More General Theory of Regulation," Journal of Law and Economics 19: $211-240$.

Sandler, T. (1996) "A Game Theoretic Analysis of Carbon Emissions," in R. D. Congleton, Ed., The Political Economy of Environmental Protection. 
Schmidt, C. (1999) "Incentives for International Environmental Cooperation: Theoretic Models and Economic Instruments." Chapter 10 of Schulze, G. G. and Ursprung, H. W. Eds. Globalization and the Environment. New York: Oxford University Press.

Schulze, G. G. and Ursprung, H. W., Eds. (2001) Globalization and the Environment. New York: Oxford University Press.

Telser, L. (1980) "A Theory of Self-Enforcing Agreements," Journal of Business 53: 27-44.

Tollison R. D. and Willett, T. D. (1979) "An Economic Theory of Mutually Advantageous Issue Linkages in International Negotiations," International Organization 33: 309-346.

Vaubel, R. and Willett, T. D., Eds. (1991) The Political Economy of International Organizations, Boulder: Westview Press. 